\title{
ВОЗНИКНОВЕНИЕ В КПСС ПОЛИТИЧЕСКИХ ДВИЖЕНИЙ И ИХ ДЕЯТЕЛЬНОСТЬ В ПЕРИОД ПОДГОТОВКЕ И РАБОТЫ XXVIII СЪЕЗДА КПСС
}

\section{THE EMERGENCE OF POLITICAL MOVEMENTS IN THE CPSU AND THEIR ACTIVITIES DURING THE PREPARATION AND WORK OF THE XXVIII CONGRESS OF THE CPSU}

\section{Osina}

Summary: During the period of perestroika, democratization and glasnost, various platforms began to form in the CPSU, which at the last stage of the USSR's existence declared a complete ideological divergence and a break with the Communist Party. The paper considers the features of the process of formation and activity of two platforms: Democratic and Marxist, during the preparation and work of the XXVIII Congress of the CPSU.

Keywords: The CPSU, the Congress, perestroika, the party, «The Democratic Platform in the CPSU», «The Marxist platform in the CPSU».
$\mathrm{X}$ VIII съезд КПСС, 2-13 июля 1990 г., не выглядит сенсацией. Для некоторых он стал большим разочарованием, ведь многие от него ожидали чего-то особенного. Одни жаждали раскола КПСС, другие ждали реформирования партии. Кто-то считал, что изменений не будет, пока М.С. Горбачев не уйдет с поста Генсека. Ничего из этого не произошло. Самым знаменательным событием Съезда стало заявление Б.Н. Ельцина о выходе из партии. Однако, Н.В. Елисеева в книге «История перестройки в СССР. 1985-1991 гг.» [7, с.346-347], пишет, что XVIII съезде стал реальной схваткой реформаторского и ортодоксального течений партии. Ортодоксальные силы всячески пытались обвинить М.С. Горбачева в потере монопольной власти КПСС. Но эти упреки не так сильно отражались на деятельности М.С. Горбачева, как Генерального секретаря ЦК КПСС, ведь к тому моменту он уже был Президентов СССР, и вышел из-под контроля партии. Труд Н.В. Елисеевой - это учебное пособие, которое носит фундаментальный характер и может претендовать на роль монографии. В.О. Коротков XXVIII съезд также рассматривает как поле открытой конфронтации между различными фракциями партийно-политической элиты [12, с.52]. В.А. Никонов, анализируя обстановку перед съездом, описывает ее как период, разрывающий саму партию [15, с.29]. Е.И. Волгин, в курсе своих лекций, характеризует Съезд как нечто, что могло снизить остроту противоречий, накопившихся в компартии за годы пере-

\author{
Осина Ольга Владимировна \\ Аспирант, Московский государственный \\ областной университет \\ olgavlshenk@rambler.ru
}

Аннотация: В период перестройки, демократизации и гласности в КПСС стали образовываться разные платформы, которые на последнем этапе существования СССР заявили о полном идейном расхождении и разрыве с коммунистической партией. В работе рассмотрены особенности процесса формирования и деятельности двух платформ: Демократической и Марксистской, в период подготовке и работы XXVIII съезда КПСС.

Ключевые слова: КПСС, съезд, перестройка, партия, «Демократическая платформа в КПСС», «Марксистская платформа в КПСС».

стройки [6, с.30-33]. Автор считает, проблема заключалась в том, что задачи, поставленные обществом перед делегатами Съезда, были слишком масштабны, фактически неосуществимыми. В том, что съезд можно было и не проводить, уверен и Н.А. Андреев. В труде «История Коммунистической партии Советского Союза» [3, с.533, 535], этому вопросу посвящен параграф «Последний раз спели «Интернационал». По мнению автора, Съезд лишь продемонстрировал одиночество М.С. Горбачева как реформатора. Н.П. Макаркин в своей работе «М.С. Горбачев и перестройка: попытка объективного анализа» основное внимание обращает на личность Генерального секретаря. Автор анализирует то, как характер М.С. Горбачева влиял на проводимые им реформы [16]. В.И. Манов-Ювенский в книге «Перестройка: Предательство? Провокация? Ошибка? Или неизбежность? Кто виноват? Что делать?», описывает события 1990-х гг. как катастрофу [14]. Невозможно обойти вниманием книгу одного из самых известных исследователей позднесоветского периода С.Г. Кара Мурзы «Крах СССР: кто виноват». Автор ищет ответ на вопрос, был ли неизбежным крах СССР.

К сожалению, в одной статье невозможно охарактеризовать взаимоотношения КПСС со всеми внутрипартийными течениями. Мы не ставим перед собой задачу высказать собственную концепцию причин децентрализации компартии. Это лишь попытка осмысления 
происходивших внутриполитических процессов, трансформации советской системе в последние годы ее существования (хронологические рамки первая половина 1990 г. - до и после XXVIII съезда КПСС). Мы обратим внимание на такие объединения как Демократическая платформа (ДП) и Марксистская платформа (МП). Именно две эти платформы стоят у истоков создания многих «неформальных» клубов.

К 1989 г. кредит прежнего, безоговорочного доверия к Генсеку, оказался практически исчерпан. Советское Общество к этому моменту можно назвать дезориентированным. Оно уже явно устало от «перестроечной» риторики о построении социализма «с человеческим лицом». Существовала необходимость предложить конкретную программу способную изменить плачевную экономическую и политическую обстановку. К 1990-м годам, уже очевидно отсутствие какого-либо плана преобразования. По наитию, в первые годы перестройки, М.С. Горбачев и его команда пытались исправить положение при помощи административных мер, к 1990-му г. такие методы уже не подходили для решения существующих социально-политических, экономических проблем.

К 1990 г. обстановку в стране можно считать критической. От безуспешных попыток решить экономические проблемы, ЦК и Политбюро перешло к модернизации политической системы. Однако после осознания того, что и эти задумки терпят фиаско, М.С. Горбачев взялся за работу над реформированием Советской федерации.1990-1991 гг. - период, когда были активированы мощные механизмы разрушения СССР. Ликвидация идеологической монополии и цензуры, ослабление внутреннего единства КПСС и возможность прихода в структурные власти людей, позиционирующих себя в качестве оппонентов режима [8]. М.С. Горбачев и его команда взялись за проблемы государственно-политического реформирования, а вот дела партии выпали из поля их зрения. Многочисленные службы ЦК вначале 1990 гг. занимались проблемами собственной реорганизацией, в связи с чем и они не могли, или не видели необходимости в реформировании КПСС. Таким образом руководство КПСС передало решение актуальных для КПСС вопросов в руки заинтересованных активистов. Необходимо отметить, что и само население СССР, которому гласность дала возможность обсуждать и предлагать дальнейшие пути реформирования, привело к активизации в КПСС общественно-политического начала. Отличительной особенностью объединений внутри КПСС было то, что и Демократическая и Марксистская платформа предлагали заняться делами «своего дома», Т.е. КПСС. В данной статье предпринята попытка анализа «модернизационных проектов», которые выдвигали эти платформы в период подготовки к XXVIII съезду партии. И Демократическая и Марксистская платформа констатировали кризисное состояние коммунистической пар- тии. Сторонники ДП считали, что упадничество носило всеобъемлющий характер: КПСС ни идеологически, ни организационно, ни политически уже не была направляющей силой. Представители Демплатформы считали, что партия умерла еще в 1920-1930 гг. По их мнению, КПСС погубили «большевистские убеждения», а идеи провозглашенные на XIX Всесоюзной конференции КПСС полностью себя исчерпали. Представители ДП призывали к «аппаратной модернизации», без которой, по их мнению, все идет к «буржуазному перерождению». Демплатформа объединила приверженцев частной собственности, плюралистической демократии. Это была сила, которая выражала ярко направленные антикоммунистические взгляды, и ратовала за социальное партнерство между трудящимися и предпринимателями. На момент своего создания ДП насчитывала 55 тыс. членов партии [17, с.15]. В марте - мае 1990 г. руководство Демократической платформы фактически решилось на оформление фракции в КПСС, т.е. началась регистрация членов ДП.

Вторая рассматриваемая нами фракция - Марксистская платформа в КПСС. Она была образована в апреле 1990 г. из ряда неформальных марксистских клубов. В числе организаторов МП были А. Бузгалин - выходец из Клуба марксистских исследований при МГУ, С. Скворцов - из Фонда социальных инициатив и др. Они также, как и представители ДП не отвергали необходимость перемен в обществе. Выступали за трансформацию деятельность КПСС, призывали к внутреннему диалогу среди членов КПСС. По мнению представителей МП именно ошибки партийной номенклатуры КПСС привели к тому, что в партию «проникли» чуждые марксизму-ленинизму взгляды. К июню 1990 г. сторонниками Марксистской платформы себя считали от 2 до $10 \%$ членов КПСС, а в регионах, где проходила активная агитация - до 15\% [4, c.40].

Необходимо обратить внимание и на положение дел в самом ЦК КПСС к весне 1990 г. Основной работой ЦК партии являлась подготовка к XXVIII съезду партии. 21-24.05.1990 г. членами ЦК обсуждался план-проект отчетного доклада на XXVIII съезде партии. Первый вариант был разработан советником Президента СССР Г.Х. Шахназаровым и помощником президента СССР по международным делам - А.С. Черняевым. 24 мая было проведено собрание при участии М.С. Горбачева, А.С. Черняева, члена Политбюро ЦК КПСС, главного редактора газеты «Правда» - И.Т. Фролова, члена Политбюро ЦК КПСС - В.А. Медведева. Именно эта команда к 28 мая подготовила, как им казалось, итоговый вариант доклада. В первом варианте, предложенном Г.Х. Шахназаровым и А.С. Черняевым, рассматривались вопросы дальнейшего реформирования партии, ее взаимодействия с обществом. Происходившие последние 5 лет преобразования Г.Х. Шахназаров и А.С. Черняев связывали не только с личной инициативой Генсека, а с пар- 
тийный аппаратом в целом. Ключевой задачей доклада им виделась необходимость показать, что партия готова перестраиваться. Акцент делался на «авангардную роль партии» [16]. В июне 1990 г. доклад еще раз претерпел изменения. М.С. Горбачев предложил сконцентрировать внимание на оценке текущих событий. Эти события он описал так: «текущий момент, его противоречия, его особенности, как и его трудности, материальные и социальные, можно правильно понять, лишь учитывая, что перед нами: другой народ, другое общество, другая партия, другие республики» [11]. Тем самым Михаил Сергеевич, очевидно, хотел сместить внимание «с руководящей роли партии», на главенствующую роль граждан Советского Союза в решении ключевых вопросов. Это было необходимо для удержания власти, ведь даже в своих воспоминаниях М.С. Горбачев характеризует период 1990 -1991 гг. как «кризис и срыв перестройки». По состоянию на апрель 1990 г., расстановка сил внутри КПСС выглядела следующим образом: 33\% - согласились с тем проектом Платформы ЦК КПСС к XXVIII съезда в том виде, в котором она была опубликована. Конечно, были и те, кто выступал за дальнейший пересмотр организационных и идеологических основ партии в рамках доработки проекта Платформы ЦК КПСС - их было 29\%. 24\% внутри КПСС были сторонниками Демократической платформы. Традиционалисты - 3\%. Были и сторонники самороспуска КПСС - 3\%. Колеблющихся было 8\% [19, с.8]. В такой нелегкий для ЦК КПСС момент, заявив о себе в январе 1990 г., «Демплатформа» взяла курс на размежевание КПСС. Гибкая, демократизированная система выборов позволила Демплатформе провести на XXVIIIсъезд около сотни своих представителей, что составляло $2 \%$ от общей массы делегатов (4 683 чел.). Представители дП выдвигали требования «передачи властных полномочий от монопольно правящей партии Советам», об отмене 6 статьи Конституции СССР. Особенно важным представители Демократической платформы считали выработку и принятие закона об общественных организациях или политических партиях. Т.е. ДП призывала к выходу фракций на легальное положение, сделать шаг в сторону многопартийности. Сторонники Демплатформы призывали признать со стороны ЦК КПСС ответственность за последствия тоталитарного режима, неверное толкование марксизма.

Ортодоксальные марксисты отрицали возможность социал-демократического пути развития СССР, что привело к увеличению количества сторонников Марксистской платформы перед съездом. Представители МП ратовали за «возвращение к классическому марксизму». Они не отрицали необходимость критического анализа теоретического наследия марксизма-ленинизма. Но эту необходимость они видели в условиях установления подлинного народовластия. МП не отрицала возможность наличия негосударственной собственности, но только в переходный период, в ограниченном размере, и под жестким контролем со стороны государства. МП в отличие от ДП не ставила задачи полного разрыва с КПСС. На II конференции сторонников МП в КПСС (16-17 июня 1990 г.) были приняты «Основные положения антикризисной программы». Это были альтернативные по отношению к правительственной программе заключения. Преодолеть кризис предлагалось «соединением неотложных мер способных остановить падение жизненного уровня и рост социального неравенства, не обусловленного трудовым вкладом..., возрождением авторитета коммунистической партии, и стратегическим мерам, которые обеспечат структурную перестройку экономики и создадут хозяйственные механизмы, стимулирующие эффективный и инициативный труд работника, коллективов, народа» [10, с.60].

Такова была расстановка политических сил перед XXVIII съездом КПСС. Все равно, наиболее многочисленной (около 40\%) среди делегатов XXVIII съезда КПСС была группа партийной номенклатуры. Однако, такая тенденция вполне объяснима [1, с.85]. Никто не захочет выпускать десятилетиями находившуюся в руках власть. Открытие форума было нестандартным. Никто не мог ожидать, что слово возьмет шахтер из магнитогорской области В. Блудов, и обвинив во всех промахах ЦК и Политбюро, предложит им уйти в отставку. После такой «разминки» съезд перешел к основному пункту повестки, заслушал доклад М.С. Горбачева «Политический отчет ЦК КПСС XXVIII съезд КПСС и задача партии». Это обращение Генсека не было похоже на то, которое гражданин Советского Союза услышали в 1986 г., на XXVII съезде КПСС.В 1986 г., когда власть только оказалась в руках М.С. Горбачева, он лишь отчитывался за ошибки предыдущего руководства, ведь «своих» промахов у него еще не было. По истечению пяти лет «перестройки» Генеральный секретарь, Президент отчитывался за работу проделанную уже под его руководством. Нельзя говорить о том, что он перекладывал с себя ответственность, но все же в своем докладе на XXVIII съезде пытался ответить тем, кто его обвинял. Михаил Сергеевич заявил, что перестройка не стала неким «сиюминутным озарением какой-то группы людей», а является логическим завершением долголетних поисков развернувшихся после XX съезда КПСС, и следующим шагов в этих поисках он считал выработку очередной программы партии [1, с.55-56, 73-76, 86-92, 97]. Предложенная Генсеком стратегия заключалась в том, чтобы сохранить существующий социалистический строй, углубить экономические и политические реформы для преодоления кризиса. Иного ожидать и не стоило. Это логически подвело к предложению принять временное программное заявления и начать работу над очередной программой партии [1, c. $55-60,73-76,86-92,97]$.

При утверждении повестки дня был поставлен вопрос о персональных отчетах членов Политбюро ЦК 
КПСС. Я. Яковлеву, В. Медведеву, Э. Шеварднадзе, Г. Разумовскому пришлось лично держать ответ перед делегатами. Особенно остро звучало выступление Б.Н. Ельцина. Российский лидер предрек скорый суд над руководством КПСС и национализацию ее имущества. В этом он видел плату за весь тот ущерб, который коммунистическое руководство нанесло стране и народу. Чтобы избежать подобной развязки, Б.Н. Ельцин предлагал собственный вариант радикальных реформ КПСС. Они во многом сходились с программой «Демплатформы».

Выход Б.Н. Ельцина из КПСС на XXVIII съезде партии «развязал руки» представителям «Демплатформы». Ее лидер В. Шостаковский от имени ДП заявил, что съезд не оправдал возложенных на него надежд. Он призывал к разделению КПСС, выходу из ее состава. Но делать это он предлагал не по одиночке, а группами, которые могли вступать в ряды «Демплатформы». Это позволило бы осенью 1990 г. провести учредительный конгресс новой демократической коалиции. Однако дальнейшие выступления представителей «Демплатформы» были несогласованными, не продолжали линию В. Шостаковского. Их позиция окончательно запутала делегатов съезда [2, с. 523-525, 608-610]. М.С. Горбачев попытался объяснить такое положение тем, что многие из ДП были не готовы отказаться от «своей доли партийного наследства» [6, с.549]. Очевидно, речь идет о зданиях, печатных органах, и финансировании. Под предлогом демократизации аппарат ЦК был готов выслушать идейные соображения неформальных организаций, но делиться за годы нажитым имуществом, им было непосильно. Анализируя предложенную программу ДП, необходимо отметить, что и она не получила большого отклика у делегатов съезда. Об этом говорят данные социологических опросов. Только 5\% выразили полную поддержку программы установкам ДП, $41 \%$ заявили о своем частичном одобрении и, наконец, 12\% констатировали полное неприятие [9, с.135]. Вместе с тем, некоторые идея предложенные представителями ДП получили свое отражение в итоговых решениях XXVIII съезда КПСС. Речь идет о замысле организационной децентрализации компартии. Решение XXVIII съезда КПСС позволило республиканским компартиям разрабатывать, конечно с учетом общепартийных положений, собственные программные документы. Разрешалось самостоятельно принимать решения по организационным, кадровым, финансово-хозяйственным, политическим и др. вопросам.

МП допускала существование в КПСС различных идейно-политических течений, но ее представители выступали против их организационного обособления. Вариант проведения выборов на фракционной основе не рассматривался в программе МП. В остальных вопросах партийной реформы активисты МП не выходили за рамки резолюций принятых на XIX партконференции. Основная идея заключалась в принципиальном подчи- нении исполнительного аппарата КПСС рядовым коммунистам. Делался упор на повышение роли первичных партийных организаций. Ключевая задача представителям МП виделась в том, чтобы не просто отдать под контроль низовым звеньям КПСС вопросы приема в партию, но и распоряжение существенной частью членских взносов. Лидеры МП предлагали не просто увеличить личную ответственность партийной элиты перед рядовыми партийцами, но и повысить ответственность за неудовлетворительное выполнение должностных обязанностей. Говоря на XXVIII съезде КПСС о внутрипартийном переустройстве, необходимо отметить уставное изменение предложенное МП, и одобренное делегатами съезда. Это новшество заключалось в разрешении коммунистам объединяться на основе различных дискуссионных платформ, но при отсутствии возможности создания фракций внутри КПСС. В демократическом русле, вполне схожим с требованиями МП, выглядят решения XXVIII съезда направленные на необходимую в сложившихся условиях либерализацию внутрипартийных отношений.

Важным итогом съезда, как для самой партии, так и для неформальных организация, стало принятия нового Устава КПСС. Конечно, он регламентировал внутреннее устройство партии. Но в условиях столь стремительно меняющейся политической системы, Устав имел куда большее значение нежели Программное заявление. Звучавшие на съезде выступления выявили полную идейнополитическую несовместимость ораторов. Объединить во многом непримиримые подходы могло бы программное заявление ЦК «К гуманному, демократическому социализму». Но этот документ будто писали две руки: правая и левая (это подметил Б.Н. Ельцин. Иронизируя - «... К туманному социализму»).

Программное заявление перекликалось с основными положениями доклада М.С. Горбачева. Уже одно его название наводило на мысль о том, что тот строй, который на протяжении десятилетий на территории СССР строила компартия - не отличался гуманизмом. «Диктатура», «произвол и беззаконие», «догматизм и нетерпение», «отчуждение человека от собственности и власти» - так в программном заявлении характеризовались «заслуги» прошлых лет. В докладе было отмечено, что дальнейшему положительному ходу перестройки мешают консерваторы-догматики, которые стремятся к авторитаризму, бюрократии. На этом фоне, в программном заявлении КПСС, компартия характеризовалась как прогрессивная, способная меняться и менять. В Программном заявлении КПСС представлялась как партия - общественного идеала. Иного услышать было невозможно. Аппарат ЦК КПСС, учитывая критическое положение в стране, решил что в Программное заявление необходимо включить перечень экстренных антикризисным мер. Партия собиралась воплощать их исключительно политическими методами. В первую очередь предлагалось разработать 
проект нового союзного договора, стабилизировать потребительский рынок посредствам переориентации экономики на социальные нужды, развивать предпринимательскую инициативу, увеличить импорт товаров широкого потребления, сократить расходы на оборону и бюрократический аппарат, прикладывать максимум для решения социальных нужд. Необходимо отметить, что социально-экономический раздел, который ранее занимал главенствующее положение, включал в себя много статистических данных, теперь лишился всякой конкретики, находился где-то на заднем плане. Относительно реформы советской федерации, партия ратовала за дальнейшее укрепление суверенитета союзных и повышения правового статуса автономных республик. М.С. Горбачев вновь вспомнил о старом большевистском тезисе о признании права нации на самоопределение, вплоть до отделения.

Некоторые исследователи, анализируя это Программное заявление, считают, что оно явилось «слепком из программных документов социал-демократии и еврокоммунистов» $[18$, с.78]. С этим сложно не согласиться. Члены ЦК КПСС стремясь сохранить власть, де-юре были готовы пойти практически на любые уступки, вот только ключевой вопрос заключается в том, чтобы могло осуществиться де-факто.

Устав, также как Программное заявление сохранял принцип централизма и авангардной роли партии. Но он не исключал возможность децентрализации КПСС. Устав расширял права первичных организаций, провозглашалось толерантное отношение к инакомыслящим, а коммунисты наделялись определенной свободной в своих политических идеях. Необходимо отметить, что большинство прописанных в Уставе демократических принципов, для рядовых партийцев так и остались «лишь прописанными обещаниями». При этом представители республиканской партийной элиты добились, по ново- му Уставу, значительных прав. Фактически документ зафиксировал самостоятельность компартий союзных республик. Появилась возможность, конечно, на базе общих документов КПСС, собственные программные и уставные положения, самостоятельно решать организационно-политические, кадровые, финансовые и прочие вопросы. В регионах компартии даже получили возможность не подчиняться решениям Политбюро и требовать рассмотрения спорных вопросов на Пленуме ЦК и ЦКК КПСС.

Очевидно нарастание поляризации членов КПСС по принципиальным политическим, идеологическим и социально-экономическим вопросам после XVIII съезда КПСС привело к тому, что процесс размежевания внутри партии фактически приобрел необратимый характер. В рамках номинально единой партии, предложившей вполне социал-демократический проект программы КПСС, как раз и противостояли объединившиеся под руководством А. Руцкого и В. Липицкого остатки Демократической платформы, теперь уже именуемой Демократической партией коммунистов России (в составе КПСС), и Марксистская платформа в КПСС. Мы убедились, что формирование их организационных структур шло довольно быстро, у каждой из них существовала своя идейно-теоретическая платформа. Основной задачей как Демократической, так и Марксистской платформы было «привлечь внимание» политически неактивной, достаточно размытой, фракционно не оформленной массы, в том числе и членов Аппарата ЦК КПСС, которые колебались вместе с генеральной линией партии.

Однозначно, к фракционному размежеванию коммунистов привела неспособность власти справиться с имеющимися, и возникающими социально-экономическими проблемами советской систем. Внутрипартийные противоречия неизбежно вели к появлению новых альтернатив общественно-политического развития страны.

\section{ЛИТЕРАТУРА}

1. XXVIII съезд Коммунистической партии Советского Союза, 2 -13 июля 1990 г.: Стеногр. отчет. Т. 1. - М.: Политиздат, 1991. - 639 с.

2. XXVIII съезд Коммунистической партии Советского Союза, 213 июля 1990 г.: Стеногр. отчет. Т. 1.-М.: Политиздат, 1991.- 623 с.

3. Андреев Н.А. Жизнь Горбачева. М.:Доброе дело, 2016. - 717 с.

4. Бузгалин А.В. Белая ворона (Последний год жизни ЦК КПСС: взгляд изнутри). М.,1993.- 211 с.

5. Волгин Е.И. Общественно-политическое объединение современной России на рубеже веков. Часть І: вторая половина 1980-х-1999 г. Курс лекций. Учебное пособие. М.: Издательство Исторического факультета МГУ, 2012. - 105 с.

6. Горбачев М.С. Жизнь и реформы. Кн. 1. М.: Новости, 1995. - 596 с.

7. Елисеева Н.В. История перестройки в СССР. 1985-1991 гг. Учебное пособие. М.: РГГУ, 2017. - 550 с.

8. Ефременко Д.В. Нормальная катастрофа: еще раз об исторических развилках 1980-1990-х гг. // Россия и современный мир. 2014. №2. С.58-80.

9. Известия ЦК КПСС. 1990. №7.

10. Известия ЦК КПСС. 1990. №9.

11. К докладу Генерального секретаря XXVIII съезда КПСС. Схема-логика доклада (24 июня 1990 г.) // Международный фонд социально-экономических и политологических исследований Горбачев-Фонд /Личный архив М.С. Горбачева. 
12. Коротков В.О. Авторитарная власть Кремля в условиях социально-политического транзита. М.: Политическая энциклопедия, 2014. - 368 с.

13. Макаркин Н.П. М.С. Горбачев и перестройка: попытка объективного анализа. М.: URSS, 2014. - 112 с.

14. Манов-Ювенский В.И. Перестройка: Предательство? Провокация? Ошибки? Или неизбежность? Кто виноват? Что делать? М.: Спутник+, 2017. - 312 с.

15. Никонов В.А. 1991 год: распад России //1991: поворот в мировой и российской истории. М.: Издательство Московского университета, 2018. С.20-46.

16. План-проект отчетного доклада ЦК КПСС. С рукописной правкой и сопроводительной запиской А.С. Черняева - Г.Х. Шахназарова (21 мая 1990 года) // Международный фонд социально-политических и политологических исследований Горбачев-ФОНД / Личный архив М.С. Горбачева.

17. Россия: партии, ассоциации, союзы, клубы. Справочник. Т.1. Ч.1.М., 1991. - 149 с.

18. Согрин В.В. Политическая история современной России. 1985-1994: От Горбачева до Ельцина. М.: Прогресс-Академия, 1994. - 192 с.

19. Тощенко Ж.Т., Бойков В.Э., Леванов Е.Е. Как обновляется КПСС (Опыт социологического анализа) // Вопросы истории КПСС, 1990. №8. С.3-14.

() Осина Ольга Владимировна (olgavlshenk@rambler.ru).

Журнал «Современная наука: актуальные проблемы теории и практики»

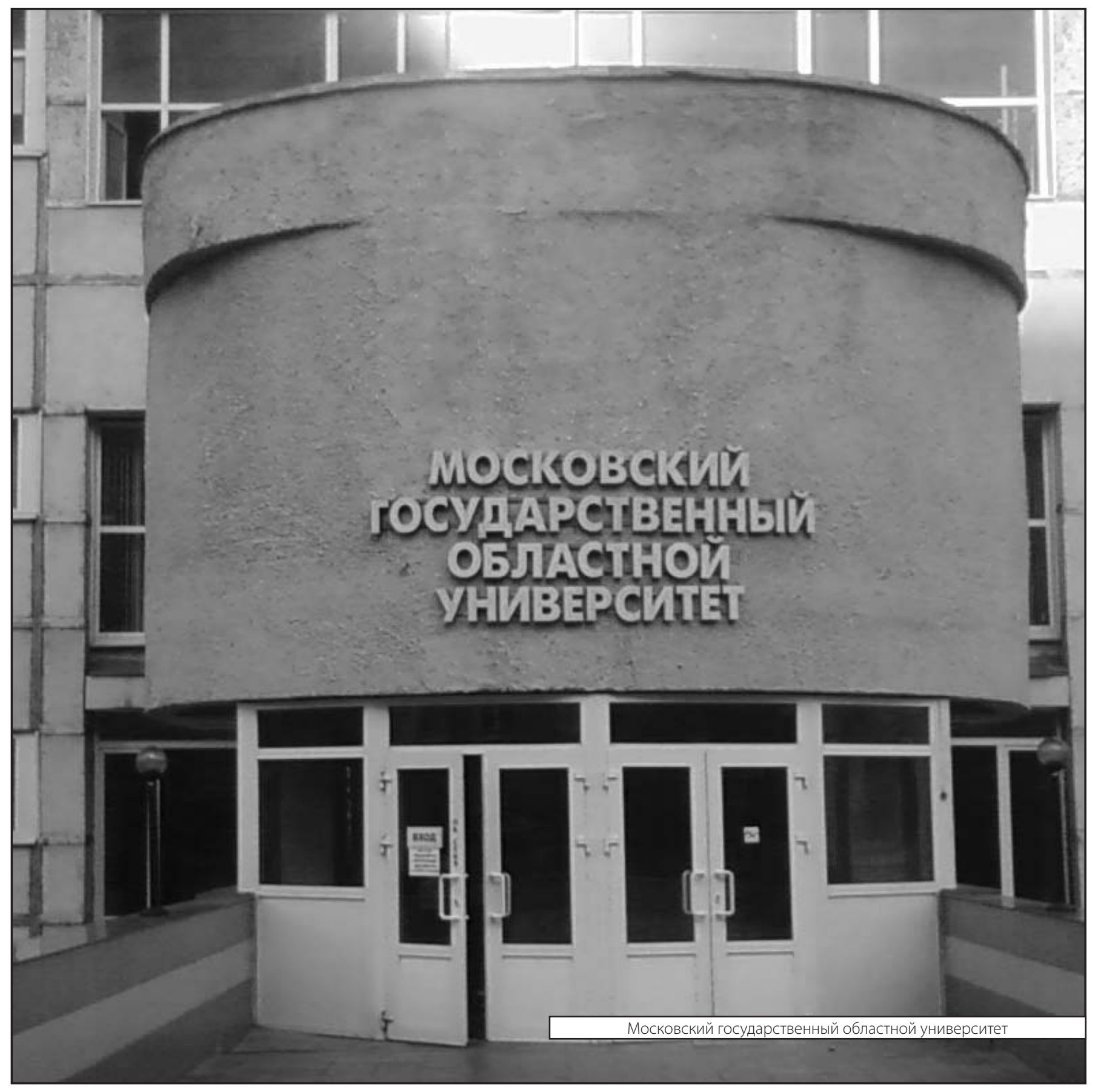

